\title{
EXECUTIVE PRIVILEGE IN THE FEDERAL COURTS
}

\author{
PAUL HARDIN, III $\dagger$
}

Courts, government officials, and writers have long struggled to solve the hard questions that arise when litigants seek production of information in the possession of government officials. ${ }^{1}$ The essential questions are (1) whether the information sought is privileged and (2) whether the government agency having possession of the information or the court in which disclosure is sought determines finally the question of privilege.

In the eyes of the executive departments and other agencies of the United States Government the two questions have but a single answer: The executive branch has the uncontrolled discretion to withhold from the courts anything whose disclosure would be inimical to the public interest ${ }^{2}$ or even, it

$\dagger$ Associate Professor of Law, Duke University.

The author is indebted to Tom Read, Second-Year Law Student at Duke, for valuable research assistance in the preparation of this article.

1. S WIGMORE, EVIDENCE $\$$ 2378-79 (McNaughton rev. 1961); MCCORMICK, EVIDENCE 302-13 (1954) ; Carrow, Governmental Nondisclosure in Judicial Proceedings, 107 U. PA. L. Rev. 166 (1958) ; Timbers \& Cohen, Demands of Litigants for Government Information, 18 U. PITT. L. REv. 687 (1957); Asbill \& Snell, Scope of Discovery Against the United States, 7 VANd. L. Rev. 582 (1954); Street, State Secrets-A Comparative Study, 14 Modern L. Rev. 121 (1951); Berger \& Krash, Government Immunity from Discovery, 59 Yale L.J. 1451 (1950); Sanford, Evidentiary Privileges Against the Production of Data Within the Control of Executive Departments, 3 VAND. L. Rev. 73 (1949); Haydock, Some Evidentiary Problems Posed by Atomic Energy Security Requirements, 61 Harv. I. Rev. 468 (1948); O'Reilly, Discovery Against the United States: A New Aspect of Sovereign Immutnity, 21 N.C.L. Rev. 1 (1942); Note, 56 Harv. L. Rev. 806 (1943) ; Annot., 32 A.L.R.2d 391 (1953) ; Comment, 36 B.U.L. Rev. 118 (1956); Comment, 18 U. ChI. L. Rev. 122 (1950); Note, 47 Nw. U.L. Rev. 519 (1952); Note, 51 Colum. L. REv. 881 (1951) ; Note, 36 Geo. L.J. 656 (1948); 197 H.L. DEB. (5th ser.) 742 (1956) ; 558 H.C. DEB. (5th ser.) 946 (1956).

The following citations are to writings that deal principally with the related problem of executive disclosure in legislative investigations, but which also shed some light on the present problem: Kramer \& Marcuse, Executive Privilege-A Study of the Period 19531960, 2 pts., 29 GEo. WasH. L. Rev. 623, 827 (1961) ; Bishop, The Executive's Right of Privacy: An Untresolved Constitutional Question, 66 Y ALE L.J. 477 (1957); Collins, The Power of Congressional Committees of Investigation to Obtain Information from the Executive Branch, 39 GEo. L.J. 563 (1951) ; Wolkinson, Demands of Congressional Committecs for Executive Papers, pts. 1-3, 10 FED. B.J. 103, 223, 319 (1949); Erhmann, The Duty of Disclosure in Parliamentary Investigation: A Comparative Study, 2 pts., $11 \mathrm{U}$. Chi. L. Rev. 1, 117 (1943) ; H.R. Rep. No. 1461, 85th Cong., 2d Sess. (1958) ; H.R. Rep. No. 2947, 84th Cong., 1st Sess. (1956).

2. Professor McCormick has suggested that an executive privilege grounded on public interest would be acceptable, so long as the judge had controlling responsibility for the balancing of the interests involved. MCCoRMICK, op. cit. supra note 1, at 303-04. Other writers ably insist that the problem of executive secrecy cannot be put as one of private versus public interests, no matter who makes the determination:

When it comes to weighing or valuing claims or demands with respect to other 
seems, to the best interest of the executive. ${ }^{3}$ The courts of the United States 4 take a different view: Whether or not information in the custody of executive departments or agencies should be disclosed in judicial proceedings de-

claims or demands, we must be careful to compare them on the same plane. If we put one as an individual interest and the other as a social interest we may decide the question in advance in our very way of putting it.

Pound, A Survey of Social Interests, 57 HARv. L. REv. 1, 2 (1943).

The public interest in a full and fair hearing of all disputes between individuals and between individuals and the state calls for the production and disclosure of all evidence relevant to the issues in dispute. This public interest calls for the production and disclosure of relevant evidence within the control of executive departments and administrative agencies.

Sanford, supra note 1 , at 73 .

As if the public interest were not involved in the administration of justice! As if the denial of justice to a single suitor were not as much a public injury as is the disclosure of any official record!

8 WIGMORE, EVIDENCE 790 (3d ed. 1940). See also Asbill \& Snell, supra note 1, at 588; Street, supra note 1, at 130; Note, 56 HARv. L. REv. 806, 814 (1943).

3. 8 WIGMoRe, op. cit. supra note 1 , at $\$ 2379$ n.2; Timbers \& Cohen, supra note 1 , at 709; Asbill \& Snell, supra note 1, at 587, 595 (citing government briefs) ; Berger \& Krash, supra note 1, at 1455; Sanford, supra note 1, at 86; Bishop, supra note 1, at 483 . The following quotations are illustrative and indicate that "expediency" and the "government interest" may loom larger than the "public interest" when the executive withholds:

Although I find nothing in the law or decisions of the courts regarding the duty of the head of an Executive Department to obey the subpoena of a court requiring him to appear as a witness, an examination of the authorities makes it clear that in the event of his so appearing he may properly refuse to testify or furnish official records, if, in his judgment, to do otherwise zeould be prejudicial to the interests of the Government or of the public. [Emphasis added.]

25 Ors. Arr'y GEN. 326, 327 (1905), citing no authority.

The rule may be stated that the President and heads of departments are not bound to produce papers or to disclose information communicated to them, where in their own judgment, the disclosure would, on public considerations, be inexpedient. [Emphasis added.]

Wolkinson, supra note 1, at 106, citing authorities that do not support the "rule."

In one case the government agency gave as a reason for withholding that the agency's staff was too busy to spare the time involved in pre-trial examination of the information sought. Bowles v. Ackerman, 4 F.R.D. 260 (S.D.N.Y. 1945).

4. The British courts have supported the right of the executive (or minister) to decide what information should be kept secret in the public interest. Duncan v. Cammell, Laird \& Co., [1942] 1 All E.R. 587; Beatson v. Skene, 5 Hurlst. \& N. 838, 157 Eng. Rep. 1415 (Ex. 1860) ; Annot., 32 A.L.R.2d 391, 399 (1953). However, Australia has not concurred, Robinsor v. State of South Australia, [1931] A.C. 704; Canada has fallen from grace, Regina v. Snider, [1954] S.C.R. 479, [1954] 4 D.L.R. 483, noted, 33 CAN. B. Rev. 352 (1955); and in the Mother Country voices have been raised against the rule permitting government officers to determine whether to disclose or whether to maintain secrecy. Allen, LAw ANd Orders 370 (2d ed. 1956) ; Street, supra note 1; Simon, Evidence Exchuded by Considerations of State Interest, 1955 Caxrb. L.J. 62. See also Comment, 35 CaN. B. REv. 200 (1957), calling attention to the dissenting voices and to probable modifications of the English view in future practice. 
pends upon a balancing of the need for disclosure against rather well defined policies-such as the policy against unnecessary dissemination of military or examining the controverted materials, in camera if need be. ${ }^{5}$ Haunting both other state secrets-and the courts must do this weighing and balancing by camps is the specter of a final clash between the executive and judicial branches over some discovery order which will necessitate definitive Supreme Court action in the troublesome constitutional area of separate powers. ${ }^{6}$

The thesis of this paper is that the executive branch has not cooperated with the judiciary to the extent that it properly should and safely could and that the courts' virtually unilateral efforts to avoid open conflict with executive officers have had some deplorable effects on the administration of justice. Perhaps by the end of the piece modest proposals for improving the situation (without jailing a cabinet officer) will emerge.

\section{An Uncooperative Executive Branch}

Evidentiary privileges well established at common law protected military and state secrets ${ }^{7}$ and the identity of government informers. ${ }^{8}$ Statutes have been enacted by Congress from time to time protecting various governmental communications and reports from public scrutiny. ${ }^{9}$ The broader power claimed by the government, to withhold information disclosure of which would not be in "the public interest," is occasionally supported by reference to the constitutional doctrine of separation of powers. ${ }^{10}$ Far more frequently, executive

5. United States v. Reynolds, 345 U.S. 1, 8, 9-10 (1953) ; Reynolds v. United States, 192 F.2d 987, 997 (3d Cir. 1951), rev'd on other grounds, 345 U.S. 1 (1953) ; NLRB v. Capitol Fish Co., 30 U.S.L. Weer 2162 (5th Cir. 1961) ; Overby v. United States Fidelity \& Guar. Co., 224 F.2d 158, 163 (5th Cir. 1955) ; Kaiser Aluminum \& Chem. Corp. v. United States, 157 F. Supp. 939, 947 (Ct. Cl. 1958) ; United States v. Procter \& Gamble Co., 25 F.R.D. 485, 489 (D. N.J. 1960) ; Morris v. Atchison, Topeka \& Santa Fe Ry., 21 F.R.D. 155, 157-58 (W.D. Mo. 1957) ; Snyder v. United States, 20 F.R.D. 7, 9 (E.D.N.Y. 1956) ; United States v. Certain Parcels of Land, 15 F.R.D. 224, 230-31 (S.D. Cal. 1954); United States v. Schneiderman, 106 F. Supp. 731, 736 (S.D. Cal. 1952) ; Evans v. United States, 10 F.R.D. 255, 257 (W.D. La. 1950) ; Cresmer v. United States, 9 F.R.D. 203, 204 (E.D. N.Y. 1949); Zimmerman v. Poindexter, 74 F. Supp. 933, 936 (D. Hawaii 1947); Walling v. Richmond Screw Anchor Co., 4 F.R.D. 265, 269 (E.D.N.Y. 1943).

6. See generally the authorities cited supra note 1 . The constitutional question will be touched upon but not treated exhaustively in this paper. The question is whether a court can finally force a department or agency head to produce documents or information in court, by contempt proceedings. It has never been done.

7. 8 WIGMORE, op. cit. supra note 1, at 794; MCCoRMICK, op. cit. supra note 1 , at $\$ 144$; Carrow, supra note 1, at 177; Asbill \& Snell, supra note 1, at 586; Sanford, supra note 1, at 74; Annot., 32 A.L.R.2d 391, 393 (1953).

8. \& WIGMORE, op. cit. supra note 1 , at $\$ 2374$; McCoRMICK, op. cit. supra note 1 , at § 148; Carrow, supra note 1, at 179; Asbill \& Snell, supra note 1, at 584; Sanford, supra note 1 , at 75 .

9. 8 WIGMORE, op. cit. supra note 1 , at $\$ 2377$; McCoRMICK, op. cit. supra note 1 , at $\$ 149$; Carrow, supra note 1, at 188; Asbill \& Snell, supra note 1, at 586; Sanford, supra note 1 , at 83.

10. Supra note 6. See also the criticism of the constitutional argument, note 47 infra. 
officers have grounded their refusal to disclose upon the so-called "housekeeping statute," which until its amendment in $1958^{11} \mathrm{read}$ as follows:

The head of each department is authorized to prescribe regulations, not inconsistent with law, for the government of his department, the conduct of its officers and clerks, the distribution and performance of its business, and the custody, use, and preservation of the records, papers, and property appertaining to it. ${ }^{12}$

Although Congress did not intend this to be a secrecy statute, ${ }^{13}$ numerous cases have cited it as the principal or sole authority for the withholding of information by the executive departments from the courts. ${ }^{14}$ Regulations prescribed by department heads on the supposed authority of that statute have been so phrased as to make secrecy the rule, cooperation with the courts the exception that must in every case be approved by the department head. ${ }^{15} \mathrm{Al}$ though they have had to look elsewhere for statutory authority, non-cabinet heads of lesser administrative agencies have obviously patterned their own

11. The 1958 amendment is discussed at notes $41-45$ infra and accompanying text.

12. Rev. Star. $\$ 161$ (1875). The statute appears, as amended in 1958, 5 U.S.C. $\$ 22$ (1958).

13. H.R. Rep. No. 1461, 85th Cong., 2d Sess. 1 (1958) ; 8 Wigmore, Evidence 795 (3d ed. 1940) ; Mitchell, Government Secrecy in Theory and Practice: "Rules and Regulations" as an Antonomous Screen, 58 CoLun. L. Rev. 199, 200 (1958); Asbill \& Snell, supra note 1, at 589; Note, 36 GEo. L.J. 656 (1948).

14. A sampling of cases: United States v. Reynolds, 345 U.S. 1 (1953); United States ex rel. Touhy v. Ragen, 340 U.S. 462 (1950) ; Boske v. Comingore, 177 U.S. 459 (1900); Mitchell v. Roma, 265 F.2d 633 (3d Cir. 1959); Bank Line, Ltd. v. United States, 163 F.2d 133 (2d Cir. 1947); Ex parte Sackett, 74 F.2d 922 (9th Cir. 1935); United States ex rel. Bayarsky v. Brooks, 51 F. Supp. 974 (D. N.J. 1943); United States v. Certain Parcels of Land, 15 F.R.D. 224 (S.D. Cal. 1954); Walling v. Comet Carriers, 3 F.R.D. 442 (S.D.N.Y. 1944).

15. Most frequently cited is Department of Justice Order No. 3229, filed May 2, 1946, 11 Fed. Reg. 4920. The second paragraph reads as follows:

Whenever a subpoena duces tecum is served to produce any of such files, documents, records or information, the officer or employee on whom such subpoena is served, unless otherwise expressly directed by the Attorney General, will appcar in court in answer thereto and respectfully decline to produce the records specified therein, on the ground that the disclosure of such records is prohibited by this regulation.

Regulations of other departments are also couched in negative terms, prohibiting any disclosure in court without the written consent of the department heads. Examples are given in 8 WIGMORE, op. cit. supra note 1 , at 800 n.11.

Since the preparation of this article Order No. 3229 has been superseded. Justice Dep't Order 260-62, 30 U.S.L. WEEK 2370 (Jan. 19, 1962). The new order provides that the attorney representing a Department of Justice officer or employee on whom a subpoena has been served shall "inform the court or other issuing authority that such person is not authorized to produce or disclose the material or information sought" and request time "within which to refer the subpoena or order to the Attorney General." If the court refuses to defer a ruling, production will be respectfully declined. While the new order increases the likelihood that decisions on these problems will be made at an appropriate level, it hardly seems destined to liberalize disclosure of governmental information. 
regulations governing access to information after those of the department heads. ${ }^{13}$ Dean Wigmore has graphically described the kind of administrative practice that these secrecy regulations engender:

This general order becomes a routine dogma in the minds of all subordinates. An application now arrives for a copy of a record material in litigation, either in a suit between private parties or in a suit by or against the government. The application is distributed, from the receiving clerk, along the line to the appropriate bureau, section, or division. The subordinate at that lowest point, obsessed by the general dogma against disclosure, prepares a reply denying the application . . . . This draft reply is sent up "through channels" (as the phrase goes), past two or more intervening superiors (each one treating it in routine fashion), till it reaches the Departmental head or other chief officer whose signature is necessary. Arriving in a ponderous pile of daily draft correspondence, it receives that necessary signature without further consideration. So the record cannot be had in the litigation; the case goes on without it; the investigation of the facts is obstructed; and maybe injustice is done. ${ }^{17}$

Obviously, the executive branch sometimes cooperates with the judiciary in making information available. ${ }^{18}$ On the other hand, occasional claims that this cooperation is generous are weakly documented, ${ }^{19}$ while evidence abounds that it is infrequent and niggardly. ${ }^{20}$

16. Agency regulations are discussed by Timbers \& Cohen, supra note 1 , at 691-92. For other examples see the Social Security Board regulation discussed in 8 WIGMORE, Evidence 792 (3d ed. 1940), and Order No. 55 of the Office of Price Administration, quoted in Bowles v. Ackerman, 4 F.R.D. 260, 261 (S.D.N.Y. 1945).

17. 8 WigMoRe, EVIDENCE 793 (3d ed. 1940).

18. See cases in which presumably the government has not argued privilege, cited in Asbill \& Snell, supra note 1, at 587 n.31. Occasionally the government, while claiming that official accident reports are privileged, nevertheless will submit the reports to the courts for in camera examination. Bentley v. United States, 16 F.R.D. 237 (M.D. Ga. 1954); Cresmer v. United States, 9 F.R.D. 203 (E.D.N.Y. 1949). See also Morris v. Atchison, Topeka \& Santa Fe Ry., 21 F.R.D. 155 (W.D. Mo. 1957) where the Post Office Department apparently cooperated fully with the court.

19. The writers of one article referred several times to the generosity of the government in making information readily available. The sources cited do not support the proposition. Timbers \& Cohen, supra note 1, at 687 n.1, and at 709 n.62a. See a similar, more acid criticism of the same article in Bishop, supra note 1, at 478 n.5.

20. A committee of the House of Representatives has concluded that "executive officials have let every file clerk become a censor." H.R. REP. No. 1461, 85th Cong., 2d Sess. 2 (1958).

Dean Pound has referred to the "reluctance of the subordinates in government departments to allow access to anything they can withhold from those with whom they are contending ...." Note, 56 HARv. L. REv. 806, 813 (1943).

Senator Hennings has characterized executive claims of privilege under the housekeeping regulations as "an insidious secrecy practice." Hennings, Constitutional Law: The Prople's Right to Know, 45 A.B.A.J. 667 (1959).

A frequently quoted statement is that of Judge Yankwich:

In all these cases, particularly in those seeking injunctive relief, the Government expects the utmost cooperation of the defendants or even prospective defendants in 
Better proof of this than the consensus of commentators are the reported cases in which executive departments and agencies have resisted disclosure. There is no typical case. While the Department of Justice is a frequent offender, the recalcitrant agency may be any executive department or administrative board. The information withheld may be almost anything, and the ostensible justification for withholding is not predictable with certainty (although the housekeeping statute figures in almost all but the latest cases). Without being unduly cynical, one can surmise that in many of the cases the information is really being withheld in order to gain advantage in the suit or to avoid official embarrassment or simply to avoid troublesome interruption of bureaucratic routine. And since withholding occurs with impartial regularity whether or not the government is an actual party to the action, the last two of these unfortunate explanations seem distressingly predominant.

The government's attitude is more defensible in some cases than in others, of course. On the whole, however, it is submitted that even randomly selected cases support the conclusion that the executive departments and agencies generally are not cooperative in making evidence available to the courts. The cases now briefly stated by way of example have been just so chosen-at random:

In one case, a private suit for damages under the antitrust laws, ${ }^{21}$ the defendant destroyed certain relevant papers. The Federal Bureau of Investigation had made copies of these papers in connection with a government injunction suit against the same defendant. The government refused to produce the copies on the ground that "it was against public policy to produce such documents because they were part of the confidential and official files of the ... Department of Justice."22

In a condemnation proceeding by the United States ${ }^{23}$ the defendant landowner sought production of the reports of government appraisers-offering to exchange reports of his own appraisers. The government resisted disclosure

placing their files and records, ranging over periods of years, at the disposal of its agents. When objection is encountered, the widest use is made of the process of the courts. A justified criticism of the Government is, however, that it is not so gcnerous in reciprocating. Thus, the Government stands on the liberal rules which allow them to plead the facts generally and resists at all stages, every attempt to compel them, through bills of particulars to supply data which would give the defendants a definite idea of the line of attack which they may expect at the trial. Judges, in our circuit, including myself, have been rather generous in compelling disclosure so as to channel the inquiry ....

Yankwich, Observations on Anti-Trust Procedures, 10 F.R.D. 165, 168 (1950).

See also Asbill \& Snell, supra note 1, at 582; Berger \& Krash, supra note 1, at 1451; and (calling attention at several places throughout the article to the English practice by which the government withholds trivia in the name of the public interest) Street, supra note 1.

21. Ex parte Sackett, 74 F.2d 922 (9th Cir. 1935).

22. Id. at 922 .

23. United States v. Certain Parcels of Land, 15 F.R.D. 224 (S.D. Cal. 1953). See also United States v. 50.34 Acres of Land, 13 F.R.D. 19 (S.D.N.Y. 1952). 
solely on the basis of Order No. 3229 of the Department of Justice, ${ }^{24}$ propounded on the authority of the housekeeping statute.

In a suit by a national bank against the surety on a bond indemnifying the bank against loss caused by defalcations of employees, the Acting Secretary of the Treasury claimed privilege and refused to produce reports of an examination of the plaintiff bank which the defendant alleged would show that the bank had had notice of the dishonest acts of its employees and had failed to notify the surety in accordance with the conditions of the bond. ${ }^{25}$

In another case, the United States had sold certain manufacturing plants to Kaiser Aluminum, promising in the contract not to offer the same type of plants to Reynolds Metals on a more favorable basis. In a suit by Kaiser claiming breach of this clause, the United States (General Services Administration) produced a number of documents relating to the sales to both companies, but claimed privilege as to one, supposedly the memorandum of a confidential assistant to the War Assets Liquidator. ${ }^{26}$

In a suit under the Federal Employers Liability Act by the widow of a former employee of the defendant railway company, the defendant subpoenaed records of the Railroad Retirement Board relating to the payment of benefits to the deceased employee, for the purpose of proving that certain payments made to the man were for illness, not injury. The Railroad Retirement Board refused to produce the records, claiming merely that they were made confidential by regulations of the Board. ${ }^{27}$

In a case brought to review a determination of the Renegotiation Board that petitioner should refund certain excess profits realized from Air Force contracts, the Board declined to produce Air Force reports relating to the performance of these contracts. ${ }^{28}$

In a suit in which it was alleged that the Reconstruction Finance Corporation had retained, from collateral, sums in excess of loans made to a certain trust company, the Reconstruction Finance Corporation refused to produce documents relating to those loans. ${ }^{29}$

Where an alien, under detention pursuant to a removal order, sought release under habeas corpus and subpoenaed the record of proceedings which resulted in the removal order, the government refused to produce the record and persisted in its refusal even after the court ordered a limited in camera production. $^{30}$

When shareholders brought an action against corporate officers and directors for misuse of corporate funds and facilities, the Securities and Exchange Commission refused to produce the results of its investigation of the affair,

24. Quoted in part at note 16 supra.

25. Overby v. United States Fidelity \& Guar. Co., 224 F.2d 158 (5th Cir. 1955).

26. Kaiser Aluminum \& Chem. Corp. v. United States, 157 F. Supp. 939 (Ct. Cl. 1958).

27. Hubbard v. Southern Ry., 179 F. Supp. 244 (M.D. Ga. 1959).

28. Petition of Boeing Airplane Company, 23 F.R.D. 264 (D.D.C. 1959).

29. Roebling v. Anderson, 257 F.2d 615 (D.C. Cir. 1958).

30. United States ex rel. Schleuter v. Watkins, 67 F. Supp. 556 (S.D.N.Y. 1946). 
on the grounds of a public policy embodied in a rule of the Commission making the results of all such investigations confidential. ${ }^{31}$

Federal Bureau of Investigation reports on the activities of the defendants in a civil case under the antitrust laws have been withheld-even to the point of suffering dismissal of the case. ${ }^{32}$

In a suit by an employee to recover overtime compensation from his employer under the Fair Labor Standards Act, the reports and documents filed by the defendant with the Salary Stabilization Unit of the Treasury Department were withheld when subpoenaed by the plaintiff. ${ }^{33}$ On the other hand, employers have their troubles in suits by the Wage-Hour Administrator to enjoin violations of the same Act. In such cases the government denies access to records of statements, affidavits, and other reports taken by government investigators from the aggrieved employees. ${ }^{34}$

The government routinely resists disclosure of official accident investigation reports in Federal Tort Claims Act cases ${ }^{35}$ and admiralty cases. ${ }^{36}$

In a criminal prosecution for refusing to be inducted into the armed services, the government withheld Federal Bureau of Investigation reports on the basis of which recommendations unfavorable to the defendant had been made to the defendant's draft board. ${ }^{37}$

In an action to enjoin violations of antitrust laws, the Department of Justice refused to produce documents relating to grand jury proceedings which the defendants contended had been conducted purely for civil suit purposes..$^{33}$ When disclosure finally was compelled, the documents established that the grand jury had indeed been misused ${ }^{39}$ - a fact providing some hint as to why the government had withheld the documents in the first place.

In an action for modification of an antitrust consent decree, the government

31. Appeal of the SEC, 226 F.2d 501 (6th Cir. 1955), discussed in Timbers \& Cohen, supra note 1.

32. United States v. Cotton Valley Operators Comm., 77 F. Supp. 409 (W.D. La. 1949), aff'd per curiam by an equally divided court, 339 U.S. 940 (1950).

33. Fowkes v. Dravo Corp., 5 F.R.D. 51 (E.D. Pa. 1945). See also Shallow v. Markert Mfg. Co., 175 Misc. 613, 24 N.Y.S.2d 823 (1941).

34. Walling v. Comet Carriers, Inc., 3 F.R.D. 442 (S.D.N.Y. 1944) ; Walling v. Richmond Screw Anchor Co., 4 F.R.D. 265 (E.D.N.Y. 1943) ; Fleming v. Bernardi, 4 F.R.D. 270 (N.D. Ohio 1941). See Mitchell v. Roma, 265 F.2d 633 (3d Cir. 1959), for proposition that the identities of complaining employees should be privileged by analogy to the informer privilege.

35. Examples: United States v. Reynolds, 345 U.S. 1 (1953) ; Adams v. United States, 260 F.2d 467 (5th Cir. 1958), cert. denied, 359 U.S. 934 (1959); Snyder v. United States, 20 F.R.D. 7 (E.D.N.Y. 1956) ; Evans v. United States, 10 F.R.D. 255 (W.D. La. 1950); Cresmer v. United States, 9 F.R.D. 203 (E.D.N.Y. 1949).

36. Bank Line, Ltd. v. United States, 163 F.2d 133 (2d Cir. 1947), wherein the official report of a naval board investigating a collision at sea was withheld because to disclose "will greatly hamper the effective functioning of the Navy Department and is prejudicial to its best interests." Id. at 136.

37. United States v. Clare, 108 F. Supp. 307 (S.D.N.Y. 1952).

38. United States v. Procter \& Gamble Co., 25 F.R.D. 485 (D. N.J. 1960).

39. United States v. Procter \& Gamble Co., 187 F. Supp. 55 (D. N.J. 1960). 
resisted disclosure of replies to government inquiries relating to economic conditions, the state of the market, and other problems in the affected industry. 40

The public interest in keeping secret from the courts the information involved in these cases ranges from non-existent to not very compelling. To withhold such information from legitimate judicial inquiry evinces a surly, uncooperative attitude and a serious default in the citizenship responsibilities of executive officers. More will be said on that subject presently.

The housekeeping statute, so frequently invoked in support of executive privilege, was amended in 1958 by the addition of this sentence:

This section does not authorize withholding information from the public or limiting the availability of records to the public. ${ }^{4 I}$

Sensing, correctly, that this addition was designed to undercut the statutory basis of a broad executive privilege, the executive branch opposed the adoption of the amendment ${ }^{42}$ and later seemed prepared to ignore it. ${ }^{43}$ It seems unlikely that the amendment heralds a new era of sweetness and light in executive cooperation with the courts. It comes too late, ${ }^{44}$ says too little, ${ }^{45}$ and, of course, leaves unimpaired the constitutional argument, such as it is. ${ }^{46}$

40. United States v. Swift \& Co., 24 F.R.D. 280 (N.D. I1l. 1959).

41. 5 U.S.C. $\$ 22$ (1958).

42. Mitchell, supra note 14, at 208-09; Timbers \& Cohen, supra note 1, at 691 n.8. Some agency comments to the Congress are summarized in H.R. REP. No. 1461, 85th Cong., 2d Sess. 8-9 (1958). The testimony of Attorney General Rogers before the Senate Judiciary Committee on March 8, 1958, has been published in 44 A.B.A.J. 941 (1958).

43. When President Eisenhower signed the amending act, he stated:

It is also clear from the legislative history of the bill that it is not intended to, and indeed could not, alter the existing power of the head of an Executive department to keep appropriate information or papers confidential in the public interest. This power in the Executive Branch is inherent under the Constitution.

White House Press Release, August 12, 1958; Public Papers of the Presidents of the United States: Dwight D. Eisenhower, 1958, p. 601.

A search through the latest supplements to the Code of Federal Regulations reveals no crash program to repeal or amend secrecy regulations propounded on the authority of the housekeeping statute before its amendment. Indeed the latest Department of Justice order on disclosure recognizes the amendment only by failing to cite the housekeeping statute as authority. See note 15 supra. As new cases arise, the executive officers are showing an awareness of the amendment, not by changing the secrecy practice, but by shifting away from their previous reliance upon the statute. Mitchell v. Roma, 265 F.2d 633, 635 (3d Cir. 1959). The pattern of the future likely will be a claim of privilege based directly upon the constitutional doctrine of the separation of powers. E.g., United States v. Procter \& Gamble Co., 25 F.R.D. 485, 489 (D. N.J. 1960).

44. Habits of secrecy established over literally decades of executive practice will not be easily arrested, even by the amendment of the statute that largely induced the habits.

45. The amendment lumps all problems of executive secrecy under the rubric of withholding information from "the public." No statute can be efficacious in this field unless it distinguishes the problem of disclosing information in court from such problems as releasing data to newspapers, congressional committees, or the public at large. More on that point later.

46. It has been doubted that there is much of a constitutional argument in support of the untrammelled discretion of the executive to withhold. Asbill \& Snell, supra note 1, at 


\section{A Compromising Judiciary}

If government officials have taken the position that the executive has an unfettered discretion to withhold information from the courts, the courts, with the approbation of most of the commentators, ${ }^{47}$ have adamantly asserted that they must finally determine what is or is not privileged..$^{48}$ Unbending adherence in a given case by each branch to its own position can create a very messy situation. In recognition of this fact the courts, particularly the appellate courts, ${ }^{49}$ have done a considerable amount of bending. ${ }^{50}$ These bending exercises, even though accompanied by metronomic proclamations of judicial authority, bid fair to produce a judicial posture of abject surrender.

The Supreme Court launched the twentieth century by acquiescing in the executive misinterpretation of the housekeeping statute. The case was Boske v. Comingore. ${ }^{51} \mathrm{~A}$ United States Collector of Internal Revenue had been held in contempt of court and jailed for refusing, while giving his deposition in a case, to file copies of reports that were in his custody as a subordinate officer of the Treasury Department. The Collector sued out a writ of habeas corpus,

595-96; Berger \& Krash, supra note 1, at 1459-60; Note, 51 Colunr. L. Rev. 881, 888 (1951). It is far too late to question the constitutional power of the courts to order executive officers to disclose information and to enforce such orders indircctly by dismissing cases or making other peremptory rulings in the event of non-compliance. Why then should direct compulsion by contempt proceedings be unconstitutional? It might be unavailing, but that is a different matter.

47. E.g., Wigmore, McCormick, Asbill \& Snell, Berger \& Krash, Carrow, Sanford, supra note 1 .

48. See cases cited note 5 sipra. The most frequently cited passage is from United States v. Reynolds, 345 U.S. 1 (1953), quoted in text at note 77 infra.

49. The trial courts generally look with disfavor on a sweeping claim of executive privilege and frequently order production of the information over such claims. In each of the following cases, for example, the district courts were firm: United States v. Reynolds, 345 U.S. 1 (1953); Olson Rug Co. v. NLRB, 291 F.2d 655 (7th Cir. 1961); Overby v. United States Fidelity \& Guar. Co., 224 F.2d 158 (5th Cir. 1955) ; Appeal of the SEC, 226 F.2d 501 (6th Cir. 1955) ; Bank Line, Ltd. v. United States, 163 F.2d 133 (2d Cir. 1947); Ex parte Sackett, 74 F.2d 922 (9th Cir. 1935); Kaiser Aluminum \& Chem. Corp. v. United States, 157 F. Supp. 939 (Ct. Cl. 1958) ; United States v. Hall, 153 F. Supp. 661 (W.D. Ky. 1957) ; United States v. Procter \& Gamble Co., 25 F.R.D. 485 (D. N.J. 1960); Mforris v. Atchison, Topeka \& Santa Fe Ry., 21 F.R.D. 155 (W.D. Mo. 1957); United States v. Certain Parcels of Land, 15 F.R.D. 224 (S.D. Cal. 1954); Durkin v. Pet Milk Co., 14 F.R.D. 385 (W.D. Ark. 1953) ; Evans v. United States, 10 F.R.D. 255 (W.D. La. 1950); United States v. Cotton Valley Operators Comm., 9 F.R.D. 719 (W.D. La. 1949) ; Cresmer v. United States, 9 F.R.D. 203 (E.D.N.Y. 1949) ; Bowles v. Ackerman, 4 F.R.D. 260 (S.D.N.Y. 1945); Fleming v. Bernardi, 4 F.R.D. 270 (N.D. Ohio 1941).

50. The House Committee on Government Operations has concluded that

The Federal courts, including the Supreme Court, have also either deliberately or unwittingly avoided the question of the use of official discretion by the head of an executive department or agency.

H.R. Rep. No. 2947, 84th Cong., 2d Sess. 90 (1956). Another writer has credited the courts with displaying "acrobatic agility" in dodging the question. Bishop, stpra note 1 , at 485 .

51. 177 U.S. 459 (1900). 
alleging that his refusal to produce this information was based upon a regulation of the Secretary of the Treasury, removing from subordinate officials any control or discretion with regard to permitting the use of such reports for any purposes other than those relating to the collection of the revenues of the United States. The district court discharged the Collector from custody. The Supreme Court, affirming, held that, since the regulation was "not inconsistent with law," ${ }^{2}$ it was authorized by the housekeeping statute.

This case lent important judicial support to the false notion that the statute was intended to authorize secrecy. Furthermore, the decision gave a hollow ring, in cases to which the government is not a party, to the courts' insistence that they and they alone decide questions of executive privilege. Subsequent cases have applied the protective cloak of Boske to subordinate employees of lesser administrative agencies in addition to those of the executive departments. ${ }^{53}$ The upshot is that in all cases involving only private litigants the only way to force disclosure of government information is the uncertain ${ }^{54}$ and unattractive ${ }^{\text {t5 }}$ device of taking deposition proceedings in Washington against the head of the department or agency, with no sanction save citation for contempt of court in the event of his refusal to produce.

The courts, saving face, nearly always point out in following Boske that the power of the courts to compel disclosure by the department or agency heads themselves is not in issue. 50 Dean Wigmore, however, has argued that, since by the very terms of most of these regulations the decision on disclosure is referred to the department or agency head, that officer's power to withhold is in issue in these cases and that the courts are abdicating their responsibility if they do not order the chief officer before the court to justify the claim

52. See the statutory language set out in the text at note 12 supra. Finding no statute that forbade adoption of the regulation, the Court perceived no ground upon which the regulation could be regarded as inconsistent with law, "unless it be that the records and papers in the office of a collector of internal revenue are at all times open of right to inspection and examination by the public, despite the wishes of the Department." Id. at 469 . Come now ! Might not such records and papers be open to inspection and examination by the courts without being open to perusal by the public?

53. Appeal of the SEC, 226 F.2d 501, 518 (6th Cir. 1955) ; Universal Airline v. Eastern Air Lines, 188 F.2d 993, 999 (D.C. Cir. 1951) ; Hubbard v. Southern Ry., 179 F. Supp. 244, 245 (M.D. Ga. 1959).

54. Professor McCormick has pointed out that

... the resort to legal process against the head will be hedged with practical difficulties such as the territorial limits upon the service of subpoena, and the probable assertion of privilege upon the taking of his deposition.

McCorarrer, op. cit. supra note 1 , at 304-05. See also Timbers \& Cohen, supra note 1 , at 689, 701 ; Note, 47 Nw. U.L. REv. 519, 523-25 (1952).

55. In one case counsel for the plaintiff announced that he would proceed collaterally against the Securities \& Exchange Commissioners in Washington, backed down when the SEC advised him that it would welcome such a test. Appeal of the SEC, 226 F.2d 501 (6th Cir. 1955). See discussion of that phase of the case by Timbers \& Cohen, supra note 1, at 705-06.

56. E.g., United States $e x$ rel. Touhy v. Ragen, 340 U.S. 462, 467, (Frankfurter, J., concurring) 472-73 (1951); Ex parte Sackett, 74 F.2d 922, 924 (9th Cir. 1935). 
of privilege. ${ }^{57}$ Professor McCormick has argued in favor of ordering disclosure in these cases, even though the court might elect not to enforce its order by a citation for contempt, on the theory that such an order would have at least the force of a declaratory judgment. ${ }^{\tilde{s}}$ However, despite these arguments that the Boske rule was bad from the outset, and despite reasonable argument that the adoption of the Federal Rules of Civil Procedure called for its abandonment, ${ }^{59}$ the rule survives. ${ }^{60}$ An educated guess is that it will continue to stand even in the face of the 1958 amendment to the statute on which the decision rested. ${ }^{61}$

At first glance the problem of executive privilege seems less acute in cases to which the government is a party because there are indirect methods of enforcing orders to the executive to produce information. ${ }^{62}$ Thus, if the government persists in its refusal to produce without demonstrating that the material is in fact privileged, the court can simply dismiss a criminal case ${ }^{03}$ or a civil case in which the government is plaintiff. ${ }^{64}$ If the government is

57. 8 WignoRe, Evidence 796 (3d ed. 1940). A recent order of the Justice Department aimed at referring problems of disclosure directly to the Attorney General lends weight to Wigmore's argument. Justice Dep't Order 260-62, supra note 15. See also Note, 25 So. CAL. L. REv. 233, 235 (1952). Evidently the agencies themselves regard demands on subordinates for production of information as demands on the agencies. Timbers \& Cohen, supra note 1, at 690 .

58. MCCoRMrck, op. cit. supra note 1, at 309. And see Comment, $18 \mathrm{U}$. CHI. L. Rev. 122,130 (1950).

59. (By rendering secrecy regulations "inconsistent with law") Berger \& Krash, supra note 1 , at 1465. But see Asbill \& Snell, supra note 1 , at $589-90$ for a different view.

60. United States ex rel. Touhy v. Ragen, 340 U.S. 462 (1951) ; Jackson v. Allen Indus., Inc., 250 F.2d 629 (6th Cir. 1958) ; Appeal of the SEC, 226 F.2d 501 (6th Cir. 1955) ; Hubbard v. Southern Ry., 179 F. Supp. 244 (M.D. Ga. 1959) ; United States ex rel. Bayarsky v. Brooks, 51 F. Supp. 974 (D. N.J. 1943) ; Harwood v. McMurtry, 22 F. Supp. 572 (W.D. Ky. 1938) ; Fowkes v. Dravo Corp., 5 F.R.D. 51 (E.D. Pa. 1945); Walling v. Comet Carriers, Inc., 3 F.R.D. 442 (S.D.N.Y. 1944).

61. Logically, since the Court expressly rested its opinion upon the housekeeping statute, the case can no longer stand unless there is new legislation. Carrow, supra note 1, at 197. However, there is some evidence that the amendment was not intended to overrule the Boske case. Mitchell, supra note 13, at 208. Furthermore, one wonders if the principle that department heads can govern the conduct of subordinates in the matter of disclosing information, established as it was on the authority of statute and regulations, is not now so thoroughly accepted as to be able to stand alone.

62. 8 Wigmore, Evidence 815 (McNaughton rev. 1961) ; Comment, 18 U. Chi. L. Rev. 122, 130 (1950); Note, 51 Colum. L. Rev. 881, 886 (1956).

63. Jencks v. United States, 353 U.S. 657 (1957) ; Roviaro v. United States, 353 U.S. 53 (1957) ; United States v. Andolschek, 142 F.2d 503 (2d Cir. 1944); United States v. Powell, 156 F. Supp. 526 (N.D. Cal. 1957). See also Christoffel v. United States, 200 F.2d 734 (D.C. Cir. 1952) ; United States v. Grayson, 166 F.2d 863, 870 (2d Cir. 1948) ; United States v. Beckman, 155 F.2d 580, 584 (2d Cir. 1946); United States v. Krulewitch, 145 F.2d 76, 78-79 (2d Cir. 1944); United States v. Evans, 115 F. Supp. 340, 343 (D. Conn. 1953).

64. United States v. Cotton Valley Operators Comm., 9 F.R.D. 719 (W.D. La. 1949), aff'd per curiam by an equally divided court, 339 U.S. 940 (1950) ; Mitchell v. Bass, 252 F.2d 513 (8th Cir. 1958) ; Fleming v. Bernardi, 4 F.R.D. 270 (N.D. Ohio 1941). 
the defendant, an order adverse to the government can be entered under Rule 37 (b) (2) of the Federal Rules of Civil Procedure ${ }^{65}$ or under the identical Admiralty Rule $32 \mathrm{C}(\mathrm{b})(2){ }^{66}$ In reality, however, the basic problem is exactly the same as the problem in cases involving only private litigants. The courts, in an effort to duck the uncertain business of enforcing discovery orders directly, ${ }^{67}$ are deciding cases without examining relevant evidencewithout regard to what the controverted information might reveal the true facts to be. Peremptory rulings against the government may lead to erroneous decisions, for it is possible that in some cases the guarded information would not be decisive of any issue but is simply being withheld because its disclosure would embarrass in some other way the administrative agency or department. How can it be said that the public interest is served when, without regard to the merits, a court dismisses a criminal case in which, after solemn deliberation, a grand jury has returned an indictment? ${ }^{68}$ Certainly, too, decisions in civil cases should be rendered upon consideration of all relevant, unprivileged evidence, rather than upon the courts' desire to avoid conflict with the executive branch.

The popular justification for the peremptory handling of these cases is that the government, by prosecuting a criminal action, by suing as plaintiff in a civil case, or by consenting to be sued civilly as a defendant, has waived its

65. Reynolds v. United States, 192 F.2d 987 (3d Cir. 1951), rev'd on other grounds, 345 U.S. 1 (1953). Rule 37(b) (2) authorizes the courts, in the event of failure of a party to comply with discovery orders, to enter such orders "as are just" including:

(i) An order that the matters regarding which the questions were asked, or the character or description of the thing or land, or the contents of the paper, or the physical or mental condition of the party, or any other designated facts shall be taken to be established for the purposes of the action in accordance with the claim of the party obtaining the order;

(ii) An order refusing to allow the disobedient party to support or oppose designated claims or defenses, or prohibiting him from introducing in evidence designated documents or things or items of testimony, or from introducing evidence of physical or mental condition;

(iii) An order striking out pleadings or parts thereof, or staying further proceedings until the order is obeyed, or dismissing the action or proceeding or any part thereof, or rendering a judgment by default against the disobedient party;

(iv) In lieu of any of the foregoing orders or in addition thereto, an order directing the arrest of any party or agent of a party for disobeying any of such orders except an order to submit to a physician or mental examination.

66. Bank Line, Ltd. v. United States, 76 F. Supp. 801 (S.D.N.Y. 1948); O'Neill v. United States, 79 F. Supp. 827 (E.D. Pa. 1948). But cf. Republic of China v. National Union Fire Ins. Co., 142 F. Supp. 551 (D. Md. 1956).

67. Professor McCormick has pointed out that the courts, even "where the interest of secrecy is a minor one," have preferred "not to incur the friction and embarrassment incident to contempt process against officials but to use the power given by the Rules ... to make an order that the matters regarding which the questions were asked shall be taken as established against the Government." McCoRMICK, op. cit. supra note 1, at 306.

68. United States v. Hall, 153 F. Supp. 661, 665 (W.D. Ky. 1957). 
privilege for governmental secrets. ${ }^{69}$ This rationalization demonstrates a complete lack of appreciation of the concepts of waiver and privilege. ${ }^{70}$

Despite the weaknesses of the approach discussed above, it has at least the virtue of resolving doubt in favor of the private litigant and against the recalcitrant executive. As much cannot be said for a third form of compromise, devised by the Supreme Court in 1953. In United States v. Reynolds ${ }^{71}$ three civilian observers were killed when an Air Force bomber crashed while testing secret equipment. Their widows filed suits under the Federal Tort Claims Act. The plaintiffs moved before trial under Rule 34 of the Federal Rules of Civil Procedure ${ }^{72}$ for production of the Air Force's official accident investigation report and the statements of the three surviving crew members taken in connection with the investigation. The district judge sustained plaintiffs' motion over a claim of privilege, holding that good cause for production of the documents had been shown. Following a more formal claim of privilege by the Secretary of the Air Force, the court ordered the documents produced so that the court might determine the question of privilege. The government declined, so the court entered an order under Rule 37 (b) (2) (i) ${ }^{73}$ that the facts on the issue of negligence would be taken as established in plaintiffs' favor. On appeal from the ultimate final judgment for plaintiffs, the Court of Appeals for the Third Circuit affirmed. ${ }^{74}$ Judge Maris considered the government's contention that the Secretary of the Air Force should determine whether or not the information sought was privileged but, with bows to Edward Livingston ${ }^{75}$ and Patrick Henry, ${ }^{76}$ decided that:

69. Cases cited notes 63-66 supra; 8 WIGMORE, EVIDENCE 812 (McNaughton rev. 1961) ; MCCoRMICK, op. cit. supra note 1, at 305-06; Asbill \& Snell, supra note 1, at 591; Berger \& Krash, supra note 1, at 1453-54.

70. It is illogical to talk of the existence of any such privilege and then find a waiver of it when the Government brings an action itself or is made a defendant, for the very purpose of a privilege is to protect certain matters in a lawsuit.

Asbill \& Snell, supra note 1, at 602 .

And while we agree that one instituting a civil suit is governed by the Federal Rules of Civil Procedure, we cannot subscribe to the suggestion that by instituting such a suit a plaintiff automatically waives any privilege accorded by the Rules, any more than the husband-wife privilege is waived if one of them institutes a suit.

Mitchell v. Roma, 265 F.2d 633, 637 (3d Cir. 1959). See also United States v. Procter \& Gamble Co., 25 F.R.D. 485, 491-92 (D. N.J. 1960); Timbers \& Cohen, supra note 1, at 719.

A cogent criticism of the waiver concept is that it ignores interests favoring secrecy and is thus a poor substitute for unfettered executive discretion which may consider only those interests. Sanford, supra note 1, at 90; Comment, 18 U. CrI. L. Rev. 122, 128 (1950).

71. 345 U.S. 1 (1953).

72. This is the rule providing for the discovery and production of documents and things in the custody of a party to a suit, upon motion and a showing of good cause.

73. Note 65 supra.

74. Reynolds v. United States, 192 F.2d 987 (3d Cir. 1951).

75. No nation ever yet found any inconvenience from too close an inspection into the conduct of its officers, but many have been brought to ruin, and reduced to slavery, 
... a claim of privilege against disclosing evidence relevant to the issues in a pending law suit involves a justiciable question, traditionally within the competence of the courts, which is to be determined in accordance with the appropriate rules of evidence, upon the submission of the documents in question to the judge for his examination in camera.77

Reversing, the Supreme Court said that "judicial control over the evidence in a case cannot be abdicated to the caprice of executive officers,"78 but went on to say that in camera examination would not be necessary when the government can-m

satisfy the court, from all the circumstances of the case, that there is a reasonable danger that compulsion of the evidence will expose military matters which, in the interest of national security, should not be divulged. ${ }^{70}$

Then the Court contrived a "necessity" formula that has been likened to an old-fashioned two-bucket well:80

In each case, the showing of necessity which is made will determine how far the court should probe in satisfying itself that the occasion for invoking the privilege as appropriate. Where there is a strong showing of necessity, [As one bucket comes up ... .] the claim of privilege should not be lightly accepted, [. . . the other probes deep down.] but even the most compelling necessity cannot overcome the claim of privilege if the court is ultimately satisfied that military secrets are at stake. ${ }^{81}$

As a final step, the Court took judicial notice that "this is a time of vigorous preparation for national defense," 82 and decided that on the record there was reasonable danger that the accident report would contain references to secret electronic equipment and that the showing of need was dubious in view of the Air Force's offer to produce for deposition the witnesses whose statements had been taken in connection with the official investigation.

The Court's "ingenious compromise" 83 has obvious conceptual weaknesses. In the first place a trial judge cannot accurately evaluate the litigant's show-

by suffering gradual imposition and abuses, which were imperceptible, only because the means of publicity had not been secured.

Id. at 995 .

76. [T]o cover with the veil of secrecy the common routine of business, is an abomiIbid. nation in the eyes of every intelligent man and every friend to his country.

77. Id. at 997.

78. 345 U.S. at $9-10$.

79. Id. at 10 .

80. Professor McCormick has used this figure in conversation with the writer and must take responsibility for it, since the writer has failed to turn it up elsewhere.

81. 345 U.S. at 11 .

82. Id. at 10 .

83. While it has been suggested that the question [of executive privilege] should be submitted to a tribunal created by the legislature for the sole purpose of trying issues arising from the exercise of a governmental privilege, it is believed that the holding 
ing of necessity without knowing something of the content of the information sought. ${ }^{84}$ There is no judicial algebra by which a court can determine how badly a litigant needs " $X$. ." In the Reynolds case, for example, if there were nothing in the accident investigation report which would help the plaintiffs, they had no need of it whatever. On the other hand, if the report contained evidence not otherwise available to the plaintiffs that the crash had been caused by the negligence of agents of the government, the need was compelling indeed. Furthermore, if the report contained anything of value that would not have been disclosed to the plaintiffs upon their interrogation of the surviving crew members, the offer to submit those survivors for deposition did not reduce a whit the need for that helpful information..$^{85}$

In the second place a trial judge cannot find that national security might be endangered by disclosure of something when the court has no idea what the something is-and we're back to " $X$." The middle ground struck by Reynolds is a phantom. If we assume that the executive will be honest and candid and objective, why not boldly adopt the English rule ${ }^{86}$ and frankly abdicate to the executive? If, on the other hand, we fear, as the Court apparently did, that executive caprice might be substituted for honest judgment, the only way for the court to probe the claim of privilege is to take a look at the information in question. Assume a case involving a strong likelihood of the presence of military secrets: Suppose that the plaintiffs' husbands in Reynolds had been killed by a nuclear explosion in a top secret atomic laboratory in Oak Ridge, Tennessee. If we honor even there the claim of privilege, on the basis of hunches about the litigants' need and the national security, we run the risk of protecting in the name of the public interest, not the formula for splitting the atom, but the fact that some government employee was not where he was supposed to be or that someone carelessly failed to post a warning signal. ${ }^{87}$ In the

of the United States Supreme Court in United States v. Reynolds ... effectuates a very ingenious compromise between these conflicting views.

Annot., 32 A.L.R.2d 391, 396 (1953).

84. Necessity should not be a factor in this determination. The judge cannot always make an intelligent decision as to whether a certain item of information is necessary until he knows what that information is.

Asbill \& Snell, supra note 1, at 601.

85. We agree with the district judge that it is not, under the circumstances of these cases, a sufficient answer to say that since the names of the witnesses whose statements were sought had been supplied in answer to the interrogatories, their depositions might have been taken by the plaintiffs. Obviously, this is no answer at all to their demand for the production of the investigation report.

Reynolds v. United States, 192 F.2d 987, 992 (3d Cir. 1951).

86. Note 4 supra.

87. In the Reynolds case itself, although secret equipment was aboard the plane, there was "nothing to suggest that the electronic equipment, in this case, had any causal connection with the accident." 345 U.S. at 11 . It is, then, entirely possible that nothing in the accident report so carefully protected from discovery related to any military or state secret. Important as the interests in preserving such [military] secrets are, their presence 
last analysis, if the court does not examine the information to weigh need for disclosure against the public interest in secrecy, the executive determines the question of privilege. 88

The Court arrived at this tantalizing direction that trial judges determine privilege without forcing disclosure even to themselves by analogy to the Hoffman case ${ }^{80}$ and claims of privilege under the Fifth Amendment. Someone has already said that this analogy was not particularly illuminating. ${ }^{90}$ It was not even apt. The Hoffman rule aids the hapless individual witness bedeviled by government counsel. The Reynolds case aids the government against the already overmatched private litigant.

Perhaps the early optimism that greeted the Reynolds opinion ${ }^{21}$ was rooted in the hope that executive and judicial statesmanship would lend reality to the phantom compromise. For example, if executive departments customarily claimed privilege only in cases of bona fide danger to the national security, the claim itself would carry some assurance that disclosure would not be in the "public interest." If the courts would really probe when the claim of privilege is dubious, doubtful claims would less readily be asserted. In other words, since the Court spoke in terms of military matters and national security, ${ }^{92}$ early commentators could have hoped that the attitudes of both courts and executives would be different in cases involving top secret records of the Atomic Energy Commission ${ }^{93}$ than in cases involving confidential records of

should be certain and the possibility of injury definite, before they should serve as the basis for the exclusion of relevant evidence.

Sanford, supra note 1 , at 89.

88. Apparently in Scotland the courts have the power to decide claims of crown privilege, but in doing so may not look at the document in question. This Reynolds-like solution prompted a member of the House of Commons to ask the following question of the Minister of Pensions and National Service: "Could the right hon. Gentleman elucidate one point? How do the Lords of Session in Scotland decide questions of Crown privilege without seeing the documents?"

The answer: "It is not for me, in the presence of the Lord Advocate, to speculate on such a matter." 558 H.C. DeB. (5th ser.) at 1038 (1956).

89. Hoffman v. United States, 341 U.S. 479 (1951).

90. Bishop, supra note 1 , at 481 .

91. Note 82 supra. Professor McCormick's optimism was cautious. Discussing the proposition that courts should decide questions of executive privilege, he would say only that the Reynolds case "seems to look" in that direction. McCormICK, op. cit. supra note 1 , at 309 .

92. 345 U.S. at 10-11. The writer who spoke most glowingly of the Reynolds case certainly noticed that the holding was narrow:

"Judicial control over the evidence cannot be abdicated to the caprice of executive officers." On the other hand, where military secrets are obviously involved, it is not proper for the judge to insist that the matter be submitted to him personally in camera, at least, where the party insisting on production of the document has not made a strong showing of necessity. [Emphasis added.]

Annot., supra note 82, at 396.

93. See Haydock, supra note 1. 
the Railroad Retirement Board.94 It is obvious from the recent cases among those previously discussed that the executive continues to withhold from court inspection much that could not be classified as military secrets. And the courts show signs also of losing sight of the fact that the Reynolds case turned on the probable presence of military secrets. In one case of only slight attenuation the Reynolds test of necessity was employed to protect information whose disclosure might prejudice "foreign relations." 95 In a later case in the Court of Claims Mr. Justice Reed, sitting by designation, sloughed over the military secrecy aspect of Reynolds and applied the test of necessity to protect an intraoffice advisory opinion of the General Services Administration relating to the sale of certain manufacturing plants. ${ }^{96}$

There are other ways of ducking the troublesome problem of forcing the reluctant executive to produce. When reviewing an order for production the appellate court might simply find that the order below was too broad. The case can then be sent back for the entry of an order somewhat narrower in scope. Perhaps then, says the court hopefully, the executive will cooperate and the nasty question will not come up again in this case. ${ }^{97}$ Of course, for the record, the appellate court will dutifully chant that, "in the final analysis, the court and not the executive officer is to determine the validity of the claim of privilege."98 In other cases wherein the executive privilege problem is found to lurk, courts have denied discovery under the "work product" rationale of the Hickman ${ }^{99}$ and Allmont ${ }^{100}$ cases. $^{101}$ In still others the problem has been avoided by reasoning that

certain kinds of individual interests affected by Government action are not entitled to as much procedural protection as other kinds of interests, and that agency determinations affecting such interests may be based upon undisclosed information, privileged or not. ${ }^{102}$

94. See Hubbard v. Southern Ry., 179 F. Supp. 224 (M.D. Ga. 1959).

95. Republic of China v. National Union Fire Ins. Co., 142 F. Supp. 551 (D. Md. 1956). It is noteworthy that the executive had cooperated and had answered forthrightly all but one interrogatory. Id. at 555.

96. Kaiser Aluminum \& Chem. Corp. v. United States, 157 F. Supp. 939 (Ct. Cl. 1958). It is only fair to point out that Kaiser seems to have "won" the case without the document. Kaiser Aluminum \& Chem. Corp. v. United States, 287 F.2d 890 (Ct. Cl. 1961).

97. Overby v. United States Fidelity \& Guar. Co., 224 F.2d 158 (5th Cir. 1955).

98. Id. at 163 .

99. Hickman v. Taylor, 329 U.S. 495 (1947), where the Supreme Court held that a party could not, except upon a showing of necessity, gain access to the products of the opposing counsel's preparation for trial.

100. Alltmont v. United States, 177 F.2d 971 (3d Cir. 1949), where the Hicknan rule was broadened to protect from discovery materials prepared for trial by persons other than the opposing attorney himself.

101. Adams v. United States, 250 F.2d 467 (5th Cir. 1958); Snyder v. United States, 20 F.R.D. 7 (E.D.N.Y. 1956). See also United States v. Deere \& Co., 9 F.R.D. 523, 527 (D. Minn. 1949) ; Kaiser Aluminum \& Chem. Corp. v. United States, 157 F. Supp. 939, 944, 946 (Ct. Cl. 1958).

102. Carrow, supra note 1 , at 174. The writer cites cases to show that these "lesser interests" include employment in the Government, admission of aliens to the United States, 
Finally, a recent important case suggests that one way to throw the ball back to the executive and to avoid a ticklish situation for the time being is to hold that the procedures of the administrative agency whereby information was withheld from the private litigant were not authorized by the President or by Congress. ${ }^{103}$ It is not suggested that such holdings as those described in this paragraph are never made in good faith, but simply that they avoid consideration of the troublesome problem now under discussion and might occasionally be employed primarily for that purpose.

The effects upon the administration of justice of the appellate courts' evasion of responsibility in the field of executive privilege may be succinctly stated. All too many cases must be decided, dropped, or settled without the benefit of relevant, unprivileged ${ }^{104}$ evidence. This means that just solutions are reached accidentally, if at all. Finally, solutions to the cases, just or unjust, will ofttimes follow protracted, expensive pre-trial and trial proceedings in which the trial courts and private litigants must try to outbluff the government and outguess the appellate courts. ${ }^{105}$ Small wonder that tempers of trial judges sometimes ignite. ${ }^{106}$

applications for suspension of deportations, and employment in private companies holding Defense Department contracts. The case cited with reference to employment in private companies holding defense contracts, Greene v. McElroy, 254 F.2d 944 (D.C. Cir. 1958), was later reversed by the Supreme Court. Greene v. McElroy, 360 U.S. 474 (1959). However, the Court ducked the key issue by holding that the administrative procedures employed in the case were not authorized.

In addition to cases cited by Carrow, see Cafeteria \& Restaurant Workers Union v. MicElroy, 367 U.S. 886 (1961), where the Court found the authorization that was lacking in the Greene case and upheld the summary procedure that had deprived a short order cook of her job at a government operated gun factory; Mitchell v. Roma, 265 F.2d 633, 636 (3d Cir. 1959), where it was held that the interest of a defendant, in a suit to enjoin violations of the Fair Labor Standards Act, in being illumined as to the identity of complaining employees was not strong enough to overcome the informer privilege; and United States $e x$ rel. Schleuter v. Watkins, 67 F. Supp. 556 (S.D.N.Y. 1946), where it was held that an alien seeking release from custody under deportation order was not prejudiced by refusal of the District Director of Immigration and Naturalization to produce records of the proceedings that resulted in the deportation order, since the court had permitted the alien's lawyer to state in court what in his opinion the records would show.

103. Greene v. McElroy, 360 U.S. 474 (1959). This case nicely illustrates how nothing is settled when these crucial issues are avoided. Greene goes back to work (Clark, J., dissenting, 360 U.S. at $511 \mathrm{n} .3$ ) with the issue of his loyalty undecided. If he is innocent, he has been unfairly and permanently stigmatized by the whole abortive proceeding. If he is disloyal he has no business being back at work on defense contracts.

104. The writer denies that he is question-begging here and asserts that no acceptable definition of privilege encompasses the great bulk of material that is being withheld from the courts by executive officers in the name of the public interest.

105. Sometimes the "poor private litigant" does not give up and has the wherewithall to "stay with" the government and haggle over discovery of governmental secrets literally for years. The Procter and Gamble anti-trust suit provides an example. The following citations to opinions in that case dealing solely with the discovery issue point up the small chance an impecunious litigant has of forcing discovery in the face of a claim of executive privilege and suggest which side more likely gives up in the many cases that never reappear 


\section{Some Modest Proposals}

By the tone of what has gone before one might expect to find here an exegesis of the law of separate powers and an exhortation to the Supreme Court to take the first opportunity to hold that in the area of executive privilege the courts are supreme and have the undoubted power to jail for contempt a cabinet officer or even the President himself, in the event of his refusal to comply with an order for the production of information. But to the writer, an evidence teacher who speaks with diffidence in the area of constitutional law, certainty seems a doubtful virtue in our system of checks and balances. Perceptive studies of the executive privilege to withhold information from legislative committees have concluded that in this related area cautious, cooperative circling and sparring between coordinate branches of the government is to be preferred to authoritative Supreme Court delineation of their respective powers. ${ }^{107}$ Although muddled uncertainty has less to commend it when helpless private litigants are caught in the middle, it serves as a fair starting point in groping for a solution to the vexing problem of executive privilege in court. This is no brief for a prompt declaration of judicial supremacy. ${ }^{108}$

Neither, however, is it an injunction to both sides to exercise additional self-restraint. That would be the symmetrical and the objective-seeming recommendation. It has been proposed as a partial solution to the legislative-executive conflict; $;^{109}$ it has, as a matter of fact, been proposed as the solution to the judicial-executive conflict, ${ }^{110}$ but inappropriately. One can with reason

in the reports after some inconclusive holding on the privilege issue: United States v. Procter \& Gamble Co., 19 F.R.D. 122 (D. N.J. 1956) ; 19 F.R.D. 247 (D. N.J. 1956) ; 356 U.S. 677 (1958) ; 170 F. Supp. 689 (D. N.J. 1959) ; 174 F. Supp. 233 (D. N.J. 1959) ; 175 F. Supp. 198 (D. N.J. 1959) ; 180 F. Supp. 195 (D. N.J. 1960) ; 25 F.R.D. 252 (D. N.J. 1960); 25 F.R.D. 485 (D. N.J. 1960) ; 187 F. Supp. 55 (D. N.J. 1960).

106. See the incredible Appeal of the SEC, 226 F.2d 501 (5th Cir. 1955), discussed in Timbers \& Cohen, supra note 1 .

107. Kramer \& Marcuse, supra note 1, at 626, 903 ; Bishop, supra note 1, at 491. Quoting the latter:

... on the whole, a good case can be made out for the proposition that the present imprecise situation is, in fact, reasonably satisfactory. Neither the executive nor the Congress is very sure of its rights, and both evince a tactful disposition not to push the assertion of their rights to abusive extremes. Of such is the system of checks and balances.

108. Professor Bernard Schwartz apparently favors a showdown. Testifying before the House Committee on Government Operations, he stated that he would like to see a case in which the head of a department is before the Court and the Boske issue cannot be begged. H.R. ReP. No. 2947, 84th Cong., 2d Sess. 70-71 (1956).

109. Kramer \& Marcuse, sipra note 1 , at 626 :

In our judgment, certain specific procedures and considerations, together with the exercise of mutual respect and self-restraint, will lessen the keen tensions which exist when these two branches of government here collide.

110. Timbers \& Cohen, supra note 1 , at $728-29$, where, indeed, the writers seem to place the main burden of improving the situation on the courts. 
admonish the Congress to be sure that an investigation is really needed before launching it, ${ }^{111}$ and to be sure that documents are really needed before requesting them $;^{112}$ but litigants, not courts, launch law suits and seek production of documents in court, and the courts have no initiative in these matters on which to practice self-restraint. The struggle in these cases is not between two coordinate branches of the government as much as it is between the executive branch or agency and citizens who seek vindication of rights in court or who defend themselves against charges brought by the government. ${ }^{113}$ The courts are not protagonists; they are arbiters. While they should cooperate with the executive in any reasonable way, to exercise more restraint than the appellate courts are now exercising would be to surrender to the executive a power that the courts themselves do not and can not exercise-the power to withhold from litigants relevant, non-privileged evidence.

\section{Executive Statesmanship}

The power to solve or at least ameliorate the problems discussed in this paper lies chiefly in the executive branch. Far more appropriate than sweeping legislation or harsher court decisions would be serious executive introspection - followed by a voluntary liberalization of the policies relating to the disclosure of governmental secrets in court. The premier argument in favor of this course is basically a moral argument-that executive officers ought to cooperate with the courts because of the general obligations of citizenship and because of the premise that must underlie the separation of powers in our system of government, the premise that the branches will cooperate. If this argument based upon "principle" does not suffice, practical arguments appealing to the baser instinct of self-interest come to mind. Brief elaboration might be useful.

Very early in our country's history a conflict arose over the production in court of information in the custody of the Chief Executive. Chief Justice Marshall, sitting as trial judge in the trial of Aaron Burr, ${ }^{114}$ subpoenaed information in the hands of President Jefferson. Marshall asserted the power of the court to subpoena the President, examine him as a witness, and require him to produce "any paper in his possession,"115 but later in the same opinion

111. Kramer \& Marcuse, supra note 1, at 913.

112. Id. at 914.

113. A distinguished state court judge, dissenting in a case involving a struggle between the executive and legislative branches, distinguished that situation from a judicial controversy with these words:

We must distinguish what is before us, namely, a controversy as to the situs of a power of government as between two coordinate branches in the discharge of their respective functions, from a judicial proceeding in which a litigant seeks the confidential material in order to defend or prosecute a case.

Weintraub, J., Morss v. Forbes, 132 A.2d 1, 26, 24 N.J. 341, 385 (1957).

114. United States v. Burr, 25 Fed. Cas. 187, 190-93 (No. 14694) (C.C.D. Va. 1807).

115. "That the president of the United States may be subpoenaed, and examined as a 
seemed to recognize a restricted legitimate area in which executive discretion might operate. ${ }^{116}$ For his part Jefferson avowed that he had the absolute power to withhold documents sought by subpoena, ${ }^{117}$ but his eventual cooperation avoided a decisive conflict. ${ }^{118}$ This entire paper footnotes the proposition that the Burr trial did not provide a final answer to the vexing questions of executive privilege. ${ }^{119}$ The case did provide, however, a remarkable example of executive cooperation, considering Jefferson's personal feelings toward Burr, ${ }^{120}$ his distaste for the judiciary, ${ }^{121}$ and his firm belief that he could resist disclosure if he chose to do so. Subsequent generations of executives and bureaucrats have been quick to cite Jefferson's claims of executive power, ${ }^{122}$ but they have overlooked his statesmanship. Jefferson's letters, as well as his actual cooperation with Marshall, evidence his concept of the role of the President as a citizen, obligated to aid, not hamper, the administration of justice:

Reserving the necessary right of the President of the US to decide, independently of all other authority, what papers, coming to him as President, the public interests permit to be communicated, \& to whom, I as-

witness, and required to produce any paper in his possession is not controverted." Id. at 191.

116. The president, although subject to the general rules which apply to others, may have sufficient motives for declining to produce a particular paper, and those motives may be such as to restrain the court from enforcing its production. I do not think precisely with the gentlemen on either side. I can readily conceive that the President might receive a letter which it would be improper to exhibit in public, because of the manifest inconvenience of its exposure. The occasion for demanding it ought, in such a case, to be very strong, and to be fully shown to the court before its production could be insisted on. I admit, that in such a case, much reliance must be placed on the declaration of the president; and I do think that a privilege does exist to withhold private letters of a certain description.

\section{Id. at 191-92.}

117. Jefferson's views are several times expressed in his letters to George Hay, the United States District Attorney for Virginia. 9 Ford, The Writrngs of ThonaAs Jefrerson 55-64 (1898); 4 Randolph, Memoirs, Correspondence, and Miscellanies from THE Papers of THOMAas JeFFerson 83-86 (1829).

118. Jefferson produced promptly all of the documents demanded except one letter, as to which he left it to government counsel, George Hay, to withhold portions not directly material. Hay expressed his willingness to submit even that entire letter to Marshall for his opinion as to whether there were parts that ought not be made public. Berger \& Krash, supra note 1 , at $1457-58$.

119. "While both proponents and opponents of executive immunity have claimed support in the record of these proceedings, the record is actually a better source of attitudes than of precedent." Note, 51 Colun. L. Rev. 881, 882 (1951).

120. Jefferson's letters to Hay cast Jefferson in the role of prosecutor, actively participating with Hay in the planning of strategy and preparation of the Government's case. 9 FoRD, op. cit. supra note 117, at 52-64. The letter of June 19, 1807, is an especially graphic illustration of Jefferson's intense desire to see Burr convicted. Id. at 58-59; 4 RANDOLPH, op. cit. supra note 117 , at 86 .

121. 3 Beveridge, The Life of John Marshall 375-76, $384-85$ (1929).

122. Asbill \& Snell, supra note 1, at 596; Berger \& Krash, supra note 1, at 1456; Wolkinson, supra note 1 , at 227-32. 
sure you of my readiness, under that restriction, voluntarily to furnish on all occasions, whatever the purposes of justice may require. ${ }^{123}$

To these communications of papers, I will add, that if the defendant supposes there are any facts within the knolege of the Heads of departments, or of myself, which can be useful for his defence, from a desire of doing any thing our situation will permit in furtherance of justice, we shall be ready to give him the benefit of it, by way of deposition, through any persons whom the Court shall authorise to take our testimony at this place. I know, indeed, that this cannot be done, but by consent of parties; \& I therefore authorise you to give consent on the part of the US. Mr. Burr's consent will be given of course, if he supposes the testimony useful. ${ }^{124}$

In the words of a high executive officer of a more recent era, the withholding from the courts of relevant evidence "can never be justified as a means of covering mistakes, avoiding embarrassment, or for political, personal, or pecuniary reasons."125 For the government to withhold information in a suit against one of its citizens merely on the theory that disclosure would have "an untoward effect on the government's case,"126 is more than offensive to sensibilities; it is unethical. ${ }^{127}$ Equally indefensible is the cavalier, automatic withholding of files from litigants in cases to which the government is not a party and in which the government has no interest. ${ }^{128}$ It is appalling for persons in public service to permit bureaucratic routine ${ }^{129}$ and a petty proprietary attitude toward "confidential" files to outweigh elementary considerations of justice. ${ }^{130}$

123. Ietter to George Hay, 9 Ford, op. cit. supra note 117, at 55; 4 RandolPH, op. cit. sulpra note 117 , at 83 [emphasis added].

124. Letter to George Hay, 9 FoRn, op. cit. supra note 117, at 57; 4 RANDolPE, op. cit. supra note 117 , at 85 [emphasis added].

125. Rogers, Constitutional Laz: The Papers of the Executive Branch, 44 A.B.A.J. 941 (1958).

It would seem more appropriate that the Department of Justice of the United States should recognize above all persons or agencies the fundamental proposition that in our form of government the orders of the court must be respected, and thereby set an example to uphold the integrity and sanctity of the court's orders rather than to belittle a respected coordinate branch of the government.

United States v. Hall, 153 F. Supp. 661, 664 (W.D. Ky. 1957).

126. Fowkes v. Dravo Corp., 5 F.R.D. 51,53 (E.D. Pa. 1945).

127. Berger \& Krash, sipra note 1, at 1452 n.8, have suggested the analogy of Canon No. 5, American Bar Association Canons of Ethics: "The primary duty of a lawyer engaged in a public prosecution is not to convict but to see that justice is done. The suppression of facts ... capable of establishing the innocence of the accused is highly reprehensible."

128. The case of Hulbbard $v$. Southern Ry., discussed in text at note 27 supra, will serve for example.

129. This habitual governmental secrecy, says Dean Wigmore, "is generally desired for the purposes of partisan politics or personal self-interest or bureaucratic routine." 8 WigMore, Evidence 790 (3d ed. 1940).

130. It has long been considered that all persons have a duty to produce relevant evidence, upon the assumption that the interest of the public in seeing that justice 
Two readily apparent appeals to the self-interest of the executive branch support voluntary liberalization of policy in the area of executive privilege. First, the agencies and departments could cooperate with the courts far more freely than they do without risking great embarrassment or damage to departmental efficiency. To reveal information in court, especially in camera, is not the same as to release information to the newspapers or to print it and make it available in pamphlet form to the public or to disclose it to a congressional investigating committee. ${ }^{131}$ The courts are not scrutinizing the executive; they are not concerned with the general efficiency of the department or agency ${ }^{132}$ they are seeking information in behalf of a litigant, only for the sake of the light that it might shed on the particular case at bar. Even if the information disclosed in court reveals incredible mismanagement or malfeasance in the executive agency, the courts cannot withhold appropriations. Indeed, if the information is not relevant to the case or is privileged, it will get no farther than the judge's chambers. The courts are accustomed and trained to weigh objectively the need for information against the need for secrecy, ${ }^{133}$ and they have a good record of protecting privileged information. ${ }^{134}$ The ex-

is done out-weighs the right to privacy. The Rules have merely underscored that duty. Not infrequently a witness may be called and questioned for weeks in a case which does not immediately touch his interests. A corporation may be called upon to produce voluminous records and files reaching back over the years at great expense and inconvenience. The plea of administrative inconvenience to the Government stands on no higher plane. The needs of justice out-weigh considerations of convenience.

Berger \& Krash, supra note 1, at 1465.

131. The issue of whether the court or the executive is to decide questions of privilege has occasionally been obscured by stating the alternative to executive discretion in terms of public access to all government records.

Comment, 18 U. CHr. L. Rev. 122, 126 (1950). See the discussion of this aspect of the Boske opinion, supra note 53.

Anyone who doubts that the sort of solemn truthseeking that goes on in a court of law is vastly different from at least some congressional investigations might read the first two pages of the article by Bishop, supra note 1, and the description of a type of congressional investigation by Erhmann, supra note 1, at 150 .

132. In Appeal of the SEC, 226 F.2d 501, 519 (6th Cir. 1955), the appellate court chastised a district judge who stepped out of character and conducted "a searching inquisition into what he considered to be neglectful inaction of the Securities and Exchange Commission...."

133. Asbill \& Snell, supra note 1, at 597; Sanford, supra note 1, at 94 ; Note, 51 Coluar. L. REv. 881, 888 (1951).

The determination of questions of fact and the applications of legal standards thereto in passing upon the admissibility of evidence and the validity of claims of evidential privilege are traditionally the responsibility of the judge. As a public functionary he has respect for the executive's scruples against disclosure and at the same time his duties require him constantly to appraise private interests and to reconcile them with conflicting public policies. [Emphasis added.]

MCCORMTCK, op. cit. supra note 1 , at 307.

134. Berger \& Krash, supra note 1, at 1462-64 ; Comment, 18 U. CHI. L. REv. 122, 12627 (1950); Note, 25 So. CAI. L. Rev. 233, 236 (1952) ; Annot., 32 A.L.R.2d 391, 405 (1953). 
ecutive branch apparently cooperates more freely with congressional investigating committees than with the courts in making information available. ${ }^{135} \mathrm{It}$ seems impractical to withhold more where there is less to fear from disclosure. ${ }^{130}$

Second, while a final decisive clash between executive and judiciary in this area of privilege should be avoided if possible, any exhortation to the executive to cooperate should point out that failure to do so might ultimately force the judiciary into a definitive holding. ${ }^{137}$ If this should occur, the judicial branch will hold the high cards. Despite all of the ducking and evading of the issue, the courts have never abandoned the claim that they decide finally the validity of claims of executive privilege. ${ }^{138}$ They have carefully avoided any implication that cabinet officers are not amenable to process and to contempt citation. ${ }^{130}$ Finally, in the moment of truth, the judiciary has a telling advantage over the other branches, the prerogative of interpreting the Constitution. ${ }^{140}$ As anxious as the courts are to avoid the clash, it would seem that the stake of the executive is higher.

In England, where court decisions give an unlimited discretion to the executive, the crown has voluntarily relaxed its grip on great classes of information that are customarily withheld in this country and that are vitally important to the administration of justice. ${ }^{\mathbf{1 4 1}}$ Whether for moral or practical

135. Kramer \& Marcuse, supra note 1, at 627-68; Bishop, supra note 1 , at 489.

136. Of course, it should surprise no one that the agencies cooperate with the purseholding branch. But the fact that this seems to be the rule and cooperation with the judicial branch the exception supports the thesis that self-interest rather than public interest ultimately determines whether or not executive agencies will disclose information in their custody.

137. If, in litigation to which the government is not a party, a court becomes convinced that a document in the possession of the government is relevant, and if it somehow manages to satisfy itself that that information is unprivileged, and if the determination to withhold is made by a department head so that there is not presented the situation of a subordinate taking shelter behind a departmental directive, the courts may yet have to decide the ultimate reach of the executive's discretion to grant or withhold information.

Bishop, supra note 1 , at 485 .

The writer would add an alternative "if." Is it not possible that even in a case to which the government is a party, a court might someday be persuaded that justice can only be done if the information is produced, and might order production under penalty, not of peremptory disposal of the case or issue, but of contempt?

138. See cases cited at note 5 supra.

139. United States $e x$ rel. Touhy v. Ragen, 340 U.S. 462, 464 (1950); United States ex rel. Bayarsky v. Brooks, 51 F. Supp. 974,976 (D. N.J. 1943) ; United States v. Shubert, 11 F.R.D. 528, 538 (S.D.N.Y. 1951). Recall also Chief Justice Marshall's position quoted note 115 supra and accompanying text, and the strong statement of Mr. Justice Frankfurter cited note 56 supra. Timbers \& Cohen, supra note 1, at 703-04, discuss department heads' amenability to process.

140. Commentators who tend to support the executive in this controversy remark rather hopefully the care with which the judiciary traditionally asserts this prerogative. Timbers \& Cohen, supra note 1 , at 739.

141. For example, the crown has announced that it will no longer claim privilege for reports of road accidents and other accidents involving government employees, nor for 
reasons and whether by Presidential order or by other device, something similar should be done in this country. The general practice should be submission of all information concerning which there is a question of privilege for in camera inspection by the court, to determine this question. If the executive branch feels bound to treat differently bona fide military and state secrets and other highly classified information, decisions to withhold even such sensitive materials should not be made automatically by clerks who merely glance at the classification stamped upon the papers. Responsible officials should make such decisions-and only after sober, open-minded consideration has been given to declassification and limited disclosure to serve the needs of justice.

\section{Judicial "Brinkmanship"}

Before enjoining the appellate courts, holding all the cards as abovesaid, to play a better brand of poker, it is not amiss to counsel a certain care and even self-restraint on the part of trial judges. Now and again trial judges show extraordinary zeal in the pursuit of information within the custody of executive officers. Indeed, in at least one case, the judge largely took over the handling of this particular matter from the lawyer representing the private litigant. ${ }^{142}$ In another, the trial judge impatiently dismissed the government's complaint under circumstances that seemed palpably insufficient to justify it. ${ }^{143}$ Such episodes should be avoided. Furthermore, orders for production ought in many cases to be more carefully drawn than they are. They should be drawn as narrowly as possible-in order to avoid needless harrassment of the executive, to make voluntary cooperation more probable, and to make it as difficult as possible for the appellate courts to send the cases back for more narrowly drawn orders. The orders should show clearly the necessity for production in order, again, to promote cooperation and to demonstrate necessity to the Reynolds-conscious appellate courts. Finally, unless it is perfectly clear to the court that the claim of privilege is spurious, the order should be for in camera production. The trial courts have shown a surprising reluctance to take the responsibility of in camera examination, and it is quite likely that executive officials would respond more favorably to such limited orders than to unconditional orders to disclose information directly to opposing parties and counsel. ${ }^{144}$ One recent case merits citation as an example of thoughtful

medical records in respect of the health of civilian government employees. 197 H.L. DEB. (5th ser.) 742, 744 (1956).

142. Appeal of the SEC, 226 F.2d 501 (6th Cir. 1955).

143. Mitchell v. Johnson, 274 F.2d 394 (5th Cir. 1960).

144. The Department of Justice, in a June 6,1947, supplement to Order No. 3229, instructed its attorneys, in declining to honor subpoenas duces tecum under that order, to "state that the material is at hand and can be submitted to the court for determination as to its materiality to the case and whether in the best public interests the information should be disclosed." This supplemental order is set out in United States ex rel. Touhy v. Ragen, 340 U.S. 462, 464 (1950), and the Court noted in that case that no request for such limited disclosure was made below. $I d$. at 466 . There is some hint in the Supreme Court opinion that the government attorneys took the initiative and made some offer of production in 
and careful work by a trial judge who obviously was aware of the considerations discussed in this paragraph. ${ }^{145}$

The appellate courts, without looking for a fight, could stiffen up a bit and squarely affirm orders for production that have been carefully framed below. It would be salutary to shift to the executive, in good, strong cases, the onus of making some concessions to avoid outright judicial-executive conflict. The Supreme Court might well get together, obiter dicta, in an appropriate case and let it be clearly known that, while the judiciary does not want a fight with the executive, the executive has a stake in and a responsibility for avoiding such a clash. ${ }^{140}$ The Court should clearly state that the proper procedure for deciding claims of executive privilege is in camera submission of the information to the courts, whether or not the government is a party to the suit.

\section{Congressional Discrimination}

Before the Housekeeping Statute was amended, Professor McCormick recommended to the Congress, as an antidote to that statute and to the restrictive regulations issued under it, a general rule of availability of official papers relevant in litigation, together with principles and standards for the guidance of the departments in classifying records and information which would exceptionally be protected from disclosure. ${ }^{147}$ Congress has not seen fit to provide this legislation, and perhaps the executive and judicial branches can work out of the difficulty without affirmative legislative action. In any event, Congress ought to recognize that demands by the courts for executive information are of a different species than the demands of the press or public or, indeed, of Congress itself. Statutes creating administrative agencies and making their records confidential should specify that they do not authorize the withholding of information from the courts when the information is needed in litigation ;148 and certainly any future remedial legislation in the area of executive privilege should deal with disclosure in court as a special problem, not merely as one aspect of the very different problem of public availability of records.

camera, to no avail. $I d$. at 465 . The supplemental order does not appear to have figured much in other cases, and there is little evidence that Justice Department attorneys routinely offer to make in cannera disclosure.

145. United States v. Procter \& Gamble Co., 25 F.R.D. 485 (D. N.J. 1960).

146. In United States $e x$ rel. Touhy v. Ragen, 340 U.S. 462, 472 (1950), Mr. Justice Frankfurter, concurring in a decision that followed the Boske case, made it clear that in his opinion department heads are amenable to process in these cases and stated emphatically that neither Boske nor the present case even hinted that "the Government can shut off an appropriate judicial demand for . . . papers." A statement of that quality by a unanimous Court might be an effective prod to the executive branch.

147. MICCoRAIICK, op. cit. supra note 1 , at 305 .

148. An example is 38 U.S.C. $\$ 3301$ (1958), which provides that all records of the Veterans' Administration shall be "confidential and privileged ... except . . . (2) When required by process of a United States court to be produced in any suit or proceeding therein pending." There seems to be no need to confine the exception to process of a United States court. In fact, Dean Wigmore has suggested that statutes providing no express exception should be construed as having an implied exception for disclosure pursuant to process of any court of justice. 8 WigMrore, EvrDENCE 801 (3d ed. 1940). 


\section{THE YALE LAW JOURNAL}

\begin{tabular}{llr}
\hline VOLUME 71 & APRIL 1962 & NUMBER 5 \\
\hline
\end{tabular}

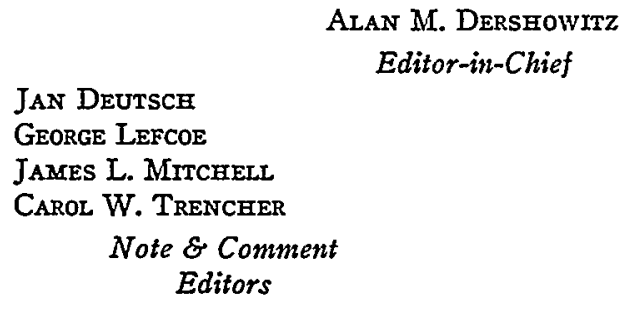

PhILIP F. JoHNSON Managing Editor

Sangwoo Ame Burton J. Ahrens Lee Albert Douglas R. Ayer Barbara A. Babcock HENRY G. BISGAIER JOSEPH S. BORUS STEPHeN A. Brown EDGAR S. CAHN Armand Derfner JoHN HART ELY
JOEL J. FrNeR

AsHIEX L. FORD

JAREES O. FrEedMaN

BRUCE E. Fritch

JAMies H. GiLlespie JoHN P. HeINZ

Algernon S. Holderness, $J_{R}$

Allen I. Isaacson

Peter G. Kelly

ANTHONY S. KolKeR

Alan H. Levine
David C. Greer

HARRY J. WeXIER

Article \& Book

Review Editors

Charles S. Battles, Jr. Topics Editor

Marie McMathon

Business Secretary

Martin Levine

JoHn T. Marshall

ALAN H. MoLod

JAMES J. MURRAY

Thomas S. Nichols

Alan R. Novar

Robert E. PhaY

Peter G. Platt

Charles F. Richards, Jr.

Sidney G. SAltz

Robert M. SHEPARD

\section{CONTRIBUTORS TO THIS ISSUE}

Arthur L. Corbin. A.B. 1894, University of Kansas; LI.B., 1899, M.A. (hon.) 1909, LL.D. (hon.) 1950, Yale University; LL.D. (hon.) 1952, University of Chicago. William K. Townsend Professor Emeritus of Law, Yale Law School.

Grant Gilmore. A.B. 1931, Yale College; Ph.D. 1936, LL.B. 1942, Yale University. Member, New York Bar. William K. Townsend Professor of Law, Yale University.

Dix W. NoEL. A.B. 1927, Harvard College; LL.B. 1930, Harvard University; M.A. 1938, Columbia University. Professor of Law, University of Tennessee.

Paul Hardin, III. A.B. 1952, LL.B. 1954, Duke University. Assistant Professor of Law, Duke University.

Alexander P. D'Entreves. Dr. Jur. 1922, Turin; Ph.D. 1932, Oxford University; M.A. 1961, Yale University. Visiting Professor of Philosophy and Law, Yale University, 19611962. 